\title{
Differences in trace metal bioaccumulation kinetics among populations of the polychaete Nereis diversicolor from metal-contaminated estuaries
}

\author{
P. S. Rainbow ${ }^{1, *}$, B. D. Smith ${ }^{1}$, S. N. Luoma ${ }^{1,2}$ \\ ${ }^{1}$ Department of Zoology, The Natural History Museum, Cromwell Road, London SW7 5BD, UK \\ ${ }^{2}$ John Muir Institute of the Environment, University of California at Davis, Davis, California 95616, USA
}

\begin{abstract}
Aquatic organisms exposed to atypically high local bioavailabilities of a toxic metal may come under selection for changes in one or more physiological processes, including the rate of metal uptake from an available source of the metal, the rate of efflux and the rate of detoxification of accumulated metal into a relatively metabolically inert form. We investigated parameters of the bioaccumulation kinetics of the toxic metals $\mathrm{Ag}, \mathrm{Cd}$ and $\mathrm{Zn}$ in populations of the estuarine polychaete worm Nereis diversicolor from differentially metal-contaminated sediments of 5 metal-rich estuaries in SW England and a relatively non-contaminated control estuary in SE England. One population (from Restronguet Creek, Cornwall) is known to be tolerant to raised availabilities of $\mathrm{Zn}$ and $\mathrm{Cu}$. We compared uptake rate constants from solution $\left(\mathrm{K}_{\mathrm{u}}\right)$ and assimilation efficiencies (AE) from sediment, and subsequent efflux rate constants $\left(\mathrm{K}_{\mathrm{e}}\right)$ after uptake (from either water or ingested sediment) for each of the 3 metals among all populations. There was some limited interpopulation variation in the biodynamic parameters controlling bioaccumulation (and potential ecotoxicity) of trace metals between populations. There did not, however, appear to be consistent patterns to such variation. The basis of Zn tolerance in the Restronguet Creek population is not due to a reduction of Zn uptake from either solution or ingested sediment, or increased efflux of $\mathrm{Zn}$ accumulated after uptake from either route. The most likely mechanism is, therefore, an increased capacity for storage detoxification of $\mathrm{Zn}$ accumulated after regulation of $\mathrm{Zn}$ body concentration has broken down.
\end{abstract}

KEY WORDS: Trace metals · Bioaccumulation · Biodynamics · Tolerance · Uptake assimilation · Efflux

\section{INTRODUCTION}

Populations of aquatic organisms exposed over the long term to atypically high local bioavailabilities of a trace metal may come under selection for changes in one or more of a variety of physiological metal bioaccumulation processes. All trace metals are toxic at some bioavailability (Luoma \& Rainbow 2008). Toxicity occurs when the rate of uptake of a metal summed across all sources (e.g. solution and diet) exceeds the combined rates of efflux and detoxification of metal into metabolically inert forms (Rainbow 2002, Luoma \& Rainbow 2005, 2008). Exposure to metal contamination, thus, could result in selection for a decreased rate constant for uptake from solution (e.g. Boisson et al. 1998), reduced efficiency of assimilation from the diet, a higher rate constant of metal loss (e.g. Postma et al. 1996), an enhanced rate of detoxification (Levinton et al. 2003), or any combination of these. Selective pressure to reduce the potential of toxic action would result in genetically based changes in such physiological traits, corresponding to the selection of a metaltolerant population (Luoma 1977, Klerks \& Weis 1987, Levinton et al. 2003, Luoma \& Rainbow 2008). Indeed the presence of a metal-tolerant population of an organism in a particular habitat provides evidence that the metal contamination of that habitat is of ecotoxicological significance, at least in one or more of the 
compartments representing a bioavailable source of metal to the species concerned (Luoma 1977).

Metal-tolerant populations of aquatic invertebrates have been identified in a number of instances in metal contaminated habitats (early examples include Bryan \& Hummerstone 1971, 1973, Bryan \& Gibbs 1983, Luoma et al. 1983, Grant et al. 1989). But there is little consistency in the literature about the processes involved in the manifestation of the tolerance. In the present study, we tested the plasticity of uptake and loss processes that could contribute to tolerance in a polychaete (Nereis diversicolor) by evaluating variability in metal uptake and loss rates among populations with different histories of exposure to metal contamination.

Changes in detoxification capabilities appear to be readily induced in invertebrates in the presence of metal contamination (e.g. Mouneyrac et al. 2003, Levinton et al. 2003, Cain et al. 2006), but changes in bioaccumulation kinetics in response to contamination exposure are more complex (e.g. Wang \& Rainbow 2005). In some cases, raised environmental exposures to a metal do not result in changes in metal bioaccumulation kinetics in populations, but in other cases they may. Rainbow et al. (1999) explored population differences in metal (Ag, Cd, Zn) uptake rates from solution among amphipods Orchestia gammarellus and crabs Carcinus maenas and Pachygrapsus marmoratus collected from different metal contaminated sites, but these did not show any consistent significant interpopulation differences. In another example, there were significant population differences in the uptake rates of dissolved $\mathrm{Cd}$ and $\mathrm{Zn}$ in the barnacle Balanus amphitrite collected from sites with different degrees of metal contamination in Hong Kong waters. But there was no significant correlation for either metal between metal uptake rate and accumulated metal concentration, a surrogate measure of previous metal exposure (Rainbow et al. 2003). There were also no significant differences in the AEs (assimilation efficiencies) of $\mathrm{Cd}$, $\mathrm{Zn}$ or Ag among these populations (Rainbow et al. 2003). Similarly, feeding on Cd or Ag-enriched diatoms by this barnacle did not change rates of uptake of $\mathrm{Cd}$, Zn or Ag from solution, nor was there a clear consistent effect of dietary pre-exposure to $\mathrm{Cd}$ or Ag on the barnacle's AE of Cd, Zn or Ag (Rainbow et al. 2004). On the other hand, Shi \& Wang (2004) compared the Cd biodynamics of 2 populations of clams Ruditapes philippinarum collected from a metal-contaminated bay (5.1 $\mathrm{\mu g} \mathrm{g}^{-1} \mathrm{Cd}$ tissue concentration) and a relatively clean site $\left(0.49 \mu \mathrm{g} \mathrm{g}^{-1} \mathrm{Cd}\right.$ tissue concentration). While there were no significant differences in the dissolved uptake rate constants, efflux rate constants or the clearance rates of the 2 populations, the contaminated clam population had significantly higher $\mathrm{Cd}$ and
Zn assimilation efficiencies compared to the uncontaminated population. Counterintuitively, the $\mathrm{Cu}$-tolerant population of the polychaete Nereis diversicolor from a contaminated estuary (Restronguet Creek) had a high rate of $\mathrm{Cu}$ accumulation compared to other populations (Bryan \& Hummerstone 1971), but this was combined with a high rate of $\mathrm{Cu}$ detoxification (Mouneyrac et al. 2003).

Recently, the development of the biodynamic model of metal bioaccumulation has represented a major advance in our understanding of metal ecotoxicology, allowing interpretation of the comparative physiological basis of different bioaccumulated metal concentrations in different species of aquatic organisms (Wang et al. 1996, Wang \& Fisher 1999, Luoma \& Rainbow 2005). Biodynamic modelling involves the quantification of biodynamic parameters that potentially underpin comparative metal bioaccumulation, coupled with relevant geochemical measurements in the field. The biodynamic model has the potential to identify critical parameters ultimately influencing accumulated metal concentration in an organism, and can be used to separate exposure pathways of metals to particular species (Luoma \& Rainbow 2005). Correspondingly, the comparative use of the biodynamic model has the potential to identify any differences between populations of the same species in key bioaccumulation processes affecting metal uptake and subsequent accumulation, with consequences for comparative differences in susceptibility to metal toxicity (Wang \& Rainbow 2006) - in short, the mechanistic basis of the evolution of metal tolerance in particular populations.

In the present study, we used biodynamic principles to investigate the bioaccumulation kinetics of the toxic metals Ag, Cd and $\mathrm{Zn}$ in populations of the estuarine polychaete worm Nereis diversicolor from differentially metal-contaminated sediments of 5 metal-rich estuaries in SW England and a relatively non-contaminated control estuary in SE England. Included is the population from Restronguet Creek, known to be tolerant to raised sedimentary availabilities of not only copper, but also zinc (Bryan \& Hummerstone 1971, 1973, Bryan \& Gibbs 1983, Grant et al. 1989). Although the $\mathrm{Cu}$ and $\mathrm{Zn}$ tolerance of this population was first demonstrated more than 30 yr ago, it has been confirmed again more recently (Mouneyrac et al. 2003), so the selective pressure for this tolerance is still present. We addressed the question of variability in biodynamic processes by comparing rate constants of uptake from solution $\left(\mathrm{K}_{\mathrm{u}}\right)$ and AEs from sediment, as well as subsequent rate constants of efflux $\left(\mathrm{K}_{\mathrm{e}}\right)$ after uptake from either water or ingested sediment of each of the 3 metals among all populations. We asked if a gradient in metal exposure history in natural populations would 
be accompanied by a similar gradient in either reduced accumulation rates or enhanced efflux rates.

Finally we tested whether existence of tolerance to a metal ( $\mathrm{Zn}$ ) was accompanied by changed biodynamics of that metal, and whether tolerance to one set of metals induced changes in rates for other metals $(\mathrm{Cu}$ and $\mathrm{Zn}$ tolerance versus Ag and Cd biodynamics). To accomplish the latter, we included among the populations Nereis diversicolor from Restronguet Creek, Cornwall, UK, a well-studied metal-contaminated estuary with a legacy of metal-rich sediments from a 150 yr-old history of mining in its catchment (Bryan \& Gibbs 1983). Restronguet Creek houses several metaltolerant populations of invertebrates (Bryan \& Hummerstone 1971, 1973, Bryan \& Gibbs 1983, Grant et al. 1989, Mouneyrac et al. 2003), substantiating the ongoing ecotoxicological significance of high local $\mathrm{Cu}$ and Zn bioavailabilities, particularly in the sediments. Metal-tolerant populations include 3 sediment-ingesting burrowing invertebrates, viz. $N$. diversicolor $(\mathrm{Cu}$ and Zn tolerant: Bryan \& Hummerstone 1971, 1973, Bryan \& Gibbs 1983, Grant et al. 1989, Mouneyrac et al. 2003), the bivalve Scrobicularia plana $(\mathrm{Cu})$ and the amphipod crustacean Corophium volutator $(\mathrm{Cu})$ (Bryan \& Gibbs 1983). Other metal-tolerant invertebrate populations in Restronguet Creek include the crab Carcinus maenas (Bryan \& Gibbs 1983), the polychaete Nephtys hombergi (Bryan \& Gibbs 1983) and nematode worms (Millward \& Grant 1995). Considering the importance of $\mathrm{Cu}$ as a metal of ecotoxicological significance in Restronguet Creek, this metal is conspicuous by its absence from the present study. The reason for this is the lack of a suitable radioisotope of $\mathrm{Cu}$, but the development of stable isotope techniques offers great potential for future investigation of this ecotoxicologically significant metal (Croteau \& Luoma 2005)

\section{MATERIALS AND METHODS}

Site descriptions. Of the estuaries chosen, Restronguet Creek receives discharge from the Carnon River draining a region with a long history of mining for metals, and correspondingly, contains extraordinarily high levels of $\mathrm{As}, \mathrm{Cu}, \mathrm{Fe}$, Mn and Zn (Bryan et al. 1980, Bryan \& Gibbs 1983, Berthet et al. 2003). The Gannel estuary has been reported to have high bioavailabilities of $\mathrm{Pb}$ and $\mathrm{Zn}$, the Tavy of $\mathrm{Cu}$, East Looe of $\mathrm{Ag}, \mathrm{Cu}$ and $\mathrm{Pb}$, and West Looe of $\mathrm{Cu}$ and $\mathrm{Pb}$ (Bryan et al. 1980). The Blackwater estuary in Essex,
SE England drains a catchment with no history of mining and was used as a control site with expectedly no atypically raised trace metal bioavailabilities. Table 1 presents comparative data on relevant metal concentrations in the sediments of these estuaries, and the differential bioaccumulation of these metals by Nereis diversicolor from each site. These data confirm that the estuarine sediments chosen provide a range of trace metal bioavailabilities to $N$. diversicolor, with particularly high sedimentary bioavailabilities to the worm of copper (Restronguet Creek, Tavy) and zinc (Restronguet Creek). Body concentrations of zinc are usually regulated to an approximately constant level by N. diversicolor (Bryan \& Hummerstone 1973, Bryan et al. 1980, Amiard et al. 1987), and the extremely high body zinc concentration in the Restronguet Creek worms denotes strong accumulation after regulation breakdown in reflection of the atypically high local zinc bioavailability. High sedimentary bioavailabilities of silver (Restronguet Creek) and perhaps cadmium (Tavy) are also represented (Table 1).

Collection. Nereis diversicolor specimens were collected from intertidal mudflats (upper $20 \mathrm{~cm}$ sediment depth) in the upper estuaries of the East Looe, Gannel, Restronguet Creek, Tavy and West Looe in southwestern England, and from the Blackwater estuary (eastern England) in 2006 and 2007 (Table 2). They were transported back to the laboratory in cool boxes in sediment from the collection site. The worms were then kept in sediment from the site of origin covered by artificial seawater (TM - Tropic Marin, Tropicarium Buchschlag, salinity $\left.16,10^{\circ} \mathrm{C}\right)$. The mean dry weights and ranges of

Table 1. Concentrations (range or mean $\pm \mathrm{SD}, \mu \mathrm{g} \mathrm{g}{ }^{-1}$ dry wt) of $\mathrm{Ag}, \mathrm{Cd}$, $\mathrm{Cu}$ and $\mathrm{Zn}$ in oxic surface sediment and Nereis diversicolor (after gut depuration) from each of 6 estuaries. Both sediments (total) and worms were dried to constant weight at $60^{\circ} \mathrm{C}$, and acid-digested in concentrated nitric acid (Aristar grade, Merck) at $100^{\circ} \mathrm{C}$, before analysis of digests on a Vista-Pro CCD Simultaneous ICP-OES. Geographic coordinates of sites in Table 2

\begin{tabular}{|lcccc|}
\hline & $\mathrm{Ag}$ & $\mathrm{Cd}$ & $\mathrm{Cu}$ & $\mathrm{Zn}$ \\
\hline Sediment & & & & \\
Blackwater & $0.46 \pm 0.09$ & $1.95 \pm 0.26$ & $24.2 \pm 3.5$ & $93 \pm 17$ \\
East Looe & $0.46 \pm 0.23$ & $0.72 \pm 0.24$ & $16.1 \pm 4.2$ & $66 \pm 15$ \\
Gannel & $0.38 \pm 0.04$ & $1.39 \pm 0.15$ & $44.0 \pm 2.8$ & $251 \pm 20$ \\
Restronguet Creek & $1.40 \pm 0.47$ & $2.85 \pm 0.28$ & $3390 \pm 290$ & $3270 \pm 260$ \\
Tavy & $0.51 \pm 0.10$ & $1.88 \pm 0.08$ & $170 \pm 16$ & $211 \pm 18$ \\
West Looe & $1.15 \pm 0.11$ & $1.41 \pm 0.14$ & $48.9 \pm 8.3$ & $103 \pm 4$ \\
Nereis diversicolor & & & & \\
Blackwater & $1.38 \pm 0.61$ & $<0.8-<2.0$ & $24.5 \pm 7.3$ & $237 \pm 37$ \\
East Looe & $2.48 \pm 0.86$ & $<1.6-<2.7$ & $46.1 \pm 24.6$ & $294 \pm 83$ \\
Gannel & $0.68 \pm 0.34$ & $<0.8-<1.9$ & $48.8 \pm 26.2$ & $258 \pm 60$ \\
Restronguet Creek & $4.82 \pm 2.01$ & $<1.0-2.3$ & $3850 \pm 1770$ & $1925 \pm 566$ \\
Tavy & $1.32 \pm 0.44$ & $2.62 \pm 0.60$ & $214 \pm 43$ & $472 \pm 90$ \\
West Looe & $2.90 \pm 8.85$ & $<1.1-<4.2$ & $71.9 \pm 28.8$ & $366 \pm 64$ \\
& & & & \\
\hline
\end{tabular}


Table 2. Collection details of the polychaete worm Nereis diversicolor from UK estuaries, with details of dry weights (mean $\pm \mathrm{SD}$ ) of worms used in dissolved metal uptake experiments. Dates are d/mo/yr

\begin{tabular}{|c|c|c|c|}
\hline Site & $\begin{array}{l}\text { Geographic } \\
\text { coordinates }\end{array}$ & $\begin{array}{l}\text { Dates of } \\
\text { collection }\end{array}$ & $\begin{array}{l}\text { Dry weights } \\
\text { (range) }\end{array}$ \\
\hline $\begin{array}{l}\text { Restronguet } \\
\text { Creek }\end{array}$ & $\begin{array}{l}050^{\circ} 12.36^{\prime} \mathrm{N} \\
005^{\circ} 05.41^{\prime} \mathrm{W}\end{array}$ & $\begin{array}{l}\text { 12/09/06, 03/04/07 } \\
\text { 03/07/07, 26/10/07 }\end{array}$ & $\begin{array}{l}0.0209 \pm 0.0104 \\
(0.0036-0.0521)\end{array}$ \\
\hline East Looe & $\begin{array}{l}050^{\circ} 22.38^{\prime} \mathrm{N} \\
004^{\circ} 27.74^{\prime} \mathrm{W}\end{array}$ & $\begin{array}{l}\text { 06/09/06, 03/04/07, } \\
\text { 03/07/07, 26/10/07 }\end{array}$ & $\begin{array}{l}0.0247 \pm 0.0176 \\
(0.0034-0.0900)\end{array}$ \\
\hline Gannel & $\begin{array}{l}050^{\circ} 24.32^{\prime} \mathrm{N} \\
005^{\circ} 05.17^{\prime} \mathrm{W}\end{array}$ & $\begin{array}{l}\text { 05/09/06, 03/04/07, } \\
\text { 03/07/07, 26/10/07 }\end{array}$ & $\begin{array}{l}0.0174 \pm 0.0135 \\
(0.0024-0.0925)\end{array}$ \\
\hline West Looe & $\begin{array}{l}050^{\circ} 21.82^{\prime} \mathrm{N} \\
004^{\circ} 28.86^{\prime} \mathrm{W}\end{array}$ & $\begin{array}{l}\text { 06/09/06, 03/04/07, } \\
\text { 03/07/07, 26/10/07 }\end{array}$ & $\begin{array}{l}0.0289 \pm 0.0171 \\
(0.0037-0.0680)\end{array}$ \\
\hline Tavy & $\begin{array}{l}050^{\circ} 27.12^{\prime} \mathrm{N} \\
004^{\circ} 10.17^{\prime} \mathrm{W}\end{array}$ & $\begin{array}{l}\text { 07/09/06, 03/04/07, } \\
\text { 03/07/07, 26/10/07 }\end{array}$ & $\begin{array}{l}0.0158 \pm 0.0088 \\
(0.0047-0.0467)\end{array}$ \\
\hline Blackwater & $\begin{array}{l}051^{\circ} 44.08^{\prime} \mathrm{N} \\
000^{\circ} 41.34^{\prime} \mathrm{E}\end{array}$ & $\begin{array}{l}\text { 13/09/06, 05/04/07 } \\
04 / 07 / 07,30 / 10 / 07\end{array}$ & $\begin{array}{l}0.0188 \pm 0.0129 \\
(0.0100-0.0947)\end{array}$ \\
\hline
\end{tabular}

In the depuration phase, radioactive contents were counted after $2 \mathrm{~h}$, and on Days 3, 4, 5, 6, 7, 10 (all metals), and on Days 12 and 14 (Zn, Ag) of depuration. Media were changed every other day and beakers were changed between labelled and unlabelled periods.

Uptake from ingested sediment. Nereis diversicolor burrows in sediment and is inevitably exposed to the water in its burrow derived from local interstitial sediment porewater and water from the overlying water transported by an irrigation current. $N$. diversicolor also ingests sediment as a food source, making it a good biomonitor of the bioavailability of many trace metals from the sediment (Bryan et al. 1980, 1985, Luoma \& Rainbow 2008). It was necessary for our purposes to offer worms collected from each site and used in dissolved uptake experiments (see below) were comparable. Worms used in the diet experiments were not weighed dry. In any experiment, worms of similar size range were distributed among metals and exposures in order to allow for any potential effect of size on biodynamic parameters measured.

Radioisotopes. Measurements involved the laboratory use of radioactive tracers of the metals $\mathrm{Ag}, \mathrm{Cd}$ and $\mathrm{Zn}$. The radioactive tracer ${ }^{110 \mathrm{M}} \mathrm{Ag}$ was obtained from Riso National Laboratory, Denmark, and ${ }^{109} \mathrm{Cd}$ and ${ }^{65} \mathrm{Zn}$ from Brookhaven National Laboratory, New York, USA. Live worms in uptake experiments (see below) were counted for contents of ${ }^{110 \mathrm{M}} \mathrm{Ag},{ }^{109} \mathrm{Cd}$ or ${ }^{65} \mathrm{Zn}$ on an LKB Wallac 1480 Wizard counter. A standard was used in each analysis to determine the background radiation level and activity changes in the samples due to radioactive decay during the experimental periods. Because the $\mathrm{Cd}$ and $\mathrm{Zn}$ tracers are essentially carrierfree, negligible concentrations of total metal were added with the addition of tracers to either water or sediment. The total concentration of Ag in the radiolabelled silver tracer was allowed for in concentration calculations where necessary.

Uptake from solution. Nereis diversicolor specimens ( $n=5$ ) from each site were exposed individually to radiolabelled $\mathrm{Cd}, \mathrm{Zn}$ and $\mathrm{Ag}$ separately $(0.25 \mu \mathrm{Ci}$ in $50 \mathrm{ml}$ medium) in acid-washed $100 \mathrm{ml}$ beakers with $50 \mathrm{ml} \mathrm{TM}$ (salinity $16,10^{\circ} \mathrm{C}$ ) at each of 3 or 4 exposure

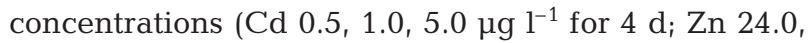
30.0, 40.0, $60.0 \mu \mathrm{g} \mathrm{l}^{-1}$ for $3 \mathrm{~d}_{\text {; }}$ Ag 0.5, 1.0, $6.0 \mu \mathrm{g} \mathrm{l}^{-1}$ for $4 \mathrm{~d}$ ) before transfer into unlabelled medium for up to a further $14 \mathrm{~d}$ (salinity 16, $10^{\circ} \mathrm{C}$ ). Each worm was counted live (see below) for radioactive $\mathrm{Cd}$, $\mathrm{Zn}$ or $\mathrm{Ag}$ content after $2 \mathrm{~h}$ (assessment of adsorption) and on Days 1, 2, 3 and 4 (not for $\mathrm{Zn}$ ) of the uptake phase. radiolabelled sediment as a food source to the worm without exposing the worm to radiolabelled metal in the porewater. We were assisted here by the diverse feeding habits of $N$. diversicolor, which include oxic sediment ingestion, sediment browsing, carnivory, scavenging and even suspension feeding via a secreted mucus net (Harley 1950). We therefore adapted a method of packaging a food item in gelatin as instigated by Wallace et al. (1998) and developed particularly for predatory gastropods (Cheung \& Wang 2005, Rainbow et al. 2007). For each metal separately, approximately $0.25 \mathrm{~g}$ of wet surface (oxic) sediment from the site of collection in the Blackwater estuary was labelled with $2 \mu \mathrm{Ci}$ of radiotracer and left to stand at $4^{\circ} \mathrm{C}$ for at least 1 mo. Before all experiments, it was confirmed that there was no significant loss of any radiolabelled metal from sediment to overlying medium. A gelatin solution was prepared (2.4 g gelatin [Sigma], in $15 \mathrm{ml}$ TM at a salinity of 16) under gentle heat, with $0.25 \mathrm{ml}$ cod liver oil (Seven Seas Health Care) added as a feeding stimulant. As this solution cooled at room temperature, radiolabelled sediment was mixed in and the mixture cooled further at $4^{\circ} \mathrm{C}$. The sediment formed a layer at the bottom held in a matrix of set gelatin and cod liver oil, and was cut into 1 to $2 \mathrm{~mm}$ cubes for feeding to the worms. The worms were 'trained' to accept such packages of sediment as a food source using unlabelled sediment treated as above.

Up to 10 individual worms from each site were allowed to feed on a package of labelled sediment, a procedure taking up to $2 \mathrm{~h}$. After feeding, each worm was counted for $30 \mathrm{~s}$; this time zero count represented the radiolabelled metal content of the ingested sediment $(100 \%)$ before any defaecation. Each worm was then kept in an acid-washed $100 \mathrm{ml}$ beaker with $50 \mathrm{ml}$ 
TM (salinity $16,10^{\circ} \mathrm{C}$ ), and counted at $8,24,32$ and $48 \mathrm{~h}$. After the first $2 \mathrm{~d}$, the worms were allowed to continue depuration of any metal and counted at less frequent intervals (e.g. Days 3, 6, 8 and 10 in the case of $\mathrm{Ag}$ ) for $10(\mathrm{Ag}, \mathrm{Zn})$ or $16(\mathrm{Cd}) \mathrm{d}$. The medium was renewed at every count. All subsequent counts were expressed as percentages of the initial count.

Statistical analysis. Parametric statistics such as regression analysis were used, employing the $p=0.05$ level of significance. Statistical comparisons were made by 1-way ANOVA or ANCOVA (Statistica for Windows, Statsoft), applying Tukey's post hoc tests for a posteriori comparisons.

\section{RESULTS}

\section{Uptake from solution}

The uptake of labelled $\mathrm{Cd}$, Ag and $\mathrm{Zn}$ from solution into the individual worms was linear over time (3 to $4 \mathrm{~d})$ at each exposure concentration, and could be modelled by a linear regression. The slope of each regression line is the uptake rate of new labelled metal ( $\mu \mathrm{g} \mathrm{g}^{-1} \mathrm{~d}^{-1}$ ) at each concentration (data not shown). These uptake rates can in turn be regressed against dissolved exposure concentration for each of the 6 worm populations. In every case the uptake rate showed a significantly linear increase $(p<0.001)$ with dissolved concentration (e.g. Fig. 1). The slope of this line (now expressed as $\mu \mathrm{g} \mathrm{g}^{-1} \mathrm{~d}^{-1}$ per $\mu \mathrm{g}^{-1}$, or $\mathrm{l} \mathrm{g}^{-1} \mathrm{~d}^{-1}$ ) is the uptake rate constant $\left(\mathrm{K}_{\mathrm{u}}\right)$, which is a unified measure of the uptake of a metal by a particular population of worms under the physico-chemical conditions used (artificial seawater, salinity $16,10^{\circ} \mathrm{C}$ ) and can be compared among the populations by ANOVA (Table 3).

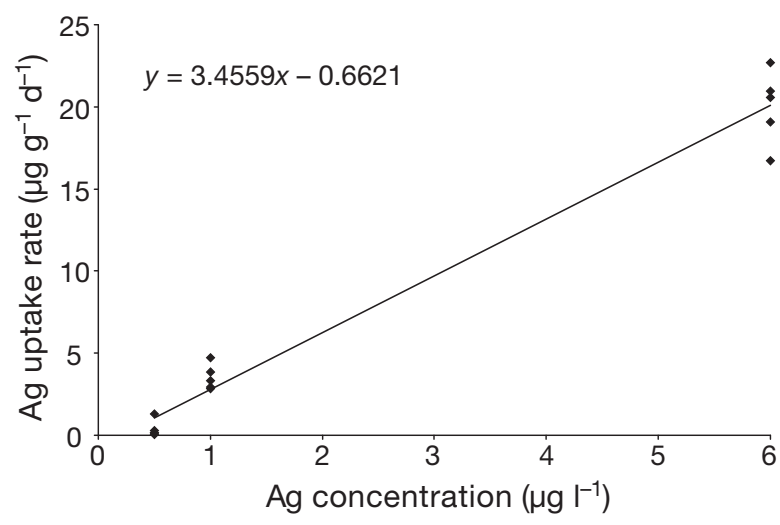

Fig. 1. Nereis diversicolor. Uptake rates of radiolabelled Ag by worms from East Looe plotted against dissolved exposure concentrations in order to estimate the uptake rate constant (regression slope, $\operatorname{l~g}^{-1} \mathrm{~d}^{-1}$ )
Table 3. Nereis diversicolor. Uptake rate constants $\left(\mathrm{K}_{\mathrm{u}}\right.$ : mean, $\mathrm{SE}, \mathrm{l} \mathrm{g}^{-1} \mathrm{~d}^{-1}$ ) of $\mathrm{Cd}$, Ag and $\mathrm{Zn}$ of polychaete worms from each of 6 populations taking up radiolabelled metal from solution. 2007 data. $\mathrm{K}_{\mathrm{u}}$ of worms from sites sharing a common letter for one metal in the a posteriori Tukey's test column do not differ significantly $(\mathrm{p}>0.05)$

\begin{tabular}{|lcccc|}
\hline & $\mathrm{K}_{\mathrm{u}}$ & $\mathrm{SE}$ & $\mathrm{n}$ & Tukey's \\
\hline Cadmium & & & & \\
Tavy & 0.0267 & 0.0027 & 14 & $\mathrm{~A}$ \\
East Looe & 0.0157 & 0.0017 & 15 & $\mathrm{~A}, \mathrm{~B}$ \\
West Looe & 0.0149 & 0.0032 & 15 & $\mathrm{~A}, \mathrm{~B}$ \\
Blackwater & 0.0134 & 0.0015 & 15 & $\mathrm{~A}, \mathrm{~B}$ \\
Gannel & 0.0115 & 0.0023 & 16 & $\mathrm{~A}, \mathrm{~B}$ \\
Restronguet Creek & 0.0087 & 0.0015 & 14 & $\mathrm{~B}$ \\
Silver & & & & \\
Tavy & 7.3353 & 0.9456 & 15 & $\mathrm{~A}$ \\
Restronguet Creek & 7.0624 & 0.5679 & 15 & $\mathrm{~A}$ \\
West Looe & 4.4229 & 0.6822 & 15 & $\mathrm{~A}, \mathrm{~B}$ \\
East Looe & 3.4559 & 0.1543 & 15 & $\mathrm{~B}, \mathrm{C}$ \\
Blackwater & 2.7856 & 0.6887 & 15 & $\mathrm{~B}, \mathrm{C}$ \\
Gannel & 1.7796 & 0.3986 & 10 & $\mathrm{C}$ \\
Zinc & & & & \\
Blackwater & 0.1021 & 0.0346 & 17 & $\mathrm{~A}$ \\
Gannel & 0.0859 & 0.0297 & 14 & $\mathrm{~A}$ \\
Tavy & 0.0752 & 0.0208 & 10 & $\mathrm{~A}$ \\
Restronguet Creek & 0.0660 & 0.0734 & 7 & $\mathrm{~A}$ \\
West Looe & 0.0336 & 0.0100 & 16 & $\mathrm{~A}$ \\
East Looe & 0.0173 & 0.0366 & 7 & $\mathrm{~A}$ \\
\hline
\end{tabular}

In the case of Cd uptake (Table 3), there was a significant difference between the $\mathrm{K}_{\mathrm{u}}$ of only 2 populations, Tavy and Restronguet Creek, with all other populations having $\mathrm{Cd} \mathrm{K}_{\mathrm{u}}$ not differing significantly from each other or from Tavy or Restronguet Creek. There was more significant variation between populations in the case of $\mathrm{Ag} \mathrm{K}_{\mathrm{u}}$ (Table 3), with Tavy and Restronguet Creek populations sharing the highest $\mathrm{Ag} \mathrm{K}_{\mathrm{u}}$, differing significantly from those of East Looe, Blackwater and Gannel populations. There were no significant differences among populations in the case of the $\mathrm{Zn}$ uptake rate constant (Table 3). In no case was the rank order of $\mathrm{K}_{\mathrm{u}} \mathrm{s}$ among populations similar to the rank order in either sediment concentration or bioaccumulated concentration found at the field site (Table 1). Nor were there dramatic differences between $\mathrm{K}_{\mathrm{u}}$ of the $\mathrm{Cu}-\mathrm{Zn}$ tolerant population from the highly contaminated Restronguet Creek and the $\mathrm{K}_{\mathrm{u}}$ values of the other populations.

Metal taken up from solution has the potential to be excreted by the worms. Fig. 2 shows such a pattern of efflux, in this case for worms from East Looe after uptake of $\mathrm{Cd}$ from solution. To calculate an efflux rate constant, counts for each worm were first expressed as percentages of the final count of the uptake phase, and these percentages are transformed logarithmically using natural logarithms (ln). The transformed data 


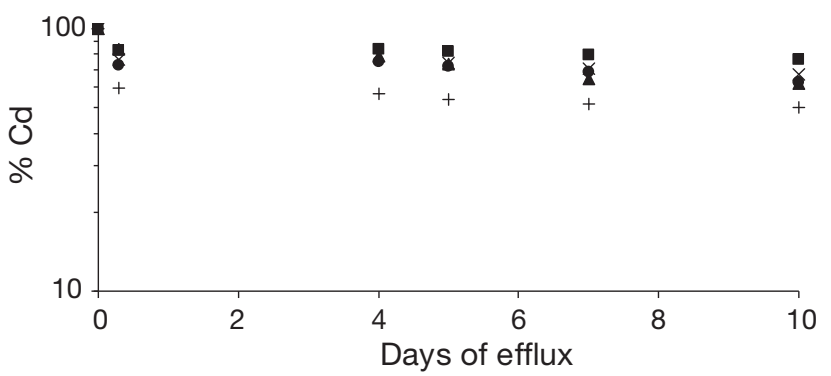

Fig. 2. Nereis diversicolor. Efflux of radiolabelled Cd accumulated from solution by individual worms (different symbols) from East Looe. Accumulated concentrations are expressed as the percentage of the amount remaining (Day 0: 100\%) on a logarithmic scale

were plotted against time (d) of efflux. In many cases, it is possible from the plot to recognise 2 phases of efflux, i.e. loss from a 'fast pool' and loss from a 'slow pool'. Of comparative interest here (and more relevant for biodynamic modelling) is the rate constant of efflux $\left(\mathrm{K}_{\mathrm{e}}\right)$ from the slow pool. Inspection of the individual patterns of efflux of metals over time showed that it was appropriate to choose different starting days for each metal for the time series describing efflux from the slow pool alone, viz. Day 3 for $\mathrm{Zn}$, Day 4 for $\mathrm{Cd}$ and Day 7 for Ag.
Table 4 presents comparative data on efflux from the slow pool of $\mathrm{Cd}, \mathrm{Ag}$ and $\mathrm{Zn}$ by the different populations of worms in terms of $\mathrm{K}_{\mathrm{e}}$, the equivalent half time (the time for half of the metal in the pool to be excreted) and the percentage of newly accumulated metal taken up from solution that was found in the slow pool.

In the case of the Gannel population, no worms survived beyond Day 7 of Ag depuration and no comparative data are presented for this population. For Cd, there were no significant differences among populations in $\mathrm{K}_{\mathrm{e}}$ after uptake from solution (Table 4). This scenario was matched closely for $\mathrm{Zn}$, although the Tavy population had an efflux rate constant from the slow pool significantly lower than those of the other 5 populations. In neither case was the highest $\mathrm{K}_{\mathrm{e}}$ twice that of the lowest $\mathrm{K}_{\mathrm{e}}$. There was more variability between populations for the $\mathrm{K}_{\mathrm{e}}$ of $\mathrm{Ag}$, as there had been for $\mathrm{K}_{\mathrm{ui}}$ the highest efflux rate constant in the East Looe population was 3 times greater than the lowest $\mathrm{K}_{\mathrm{e}}$ in the Restronguet Creek worms.

There were clear differences among metals in the relative percentages of newly accumulated metals in the fast and slow pools across all populations (Table 4). Nearly half the new Zn was present in the fast pool while, in effect, there was no fast pool for Ag; about $80 \%$ of accumulated $\mathrm{Cd}$ was in the slow pool.

Table 4. Nereis diversicolor. Efflux rate constants $\left(\mathrm{K}_{\mathrm{e}}\right.$ : mean, $\left.\mathrm{SE}, \mathrm{d}^{-1}\right)$, half times and mean (SE) percentage of newly accumulated metal held in the 'slow' pool for $\mathrm{Cd}$, Ag and $\mathrm{Zn}$ in polychaete worms from each of 6 populations (5 for Ag) after taking up radiolabelled metal from solution. 2007 data. $K_{e}$ of worms from sites sharing a common letter for one metal in the a posteriori

Tukey's test column do not differ significantly ( $\mathrm{p}>0.05$ ). Half time: the time for half of the metal in the pool to be excreted

\begin{tabular}{|c|c|c|c|c|c|c|c|}
\hline & \multirow{2}{*}{ Mean } & \multicolumn{2}{|l|}{$-\mathrm{K}_{\mathrm{e}}$} & \multirow{2}{*}{$\begin{array}{l}\text { Half time } \\
\text { (d) }\end{array}$} & \multirow{2}{*}{ Mean } & \multirow{2}{*}{$\begin{array}{c}\text { - \% 'slow' pool - } \\
\text { SE }\end{array}$} & \multirow[b]{2}{*}{$\mathrm{n}$} \\
\hline & & SE & Tukey's & & & & \\
\hline \multicolumn{8}{|l|}{ Cadmium } \\
\hline Gannel & 0.0336 & 0.0046 & A & 20.6 & 89.6 & 1.9 & 14 \\
\hline Restronguet Creek & 0.0312 & 0.0046 & A & 22.2 & 71.5 & 3.1 & 14 \\
\hline Tavy & 0.0311 & 0.0050 & A & 22.3 & 80.2 & 2.1 & 14 \\
\hline West Looe & 0.0243 & 0.0027 & A & 28.5 & 81.4 & 3.4 & 13 \\
\hline East Looe & 0.0217 & 0.0029 & $\mathrm{~A}$ & 31.9 & 76.9 & 3.2 & 14 \\
\hline Blackwater & 0.0184 & 0.0018 & $\mathrm{~A}$ & 37.7 & 81.9 & 2.4 & 14 \\
\hline \multicolumn{8}{|l|}{ Silver } \\
\hline East Looe & 0.0518 & 0.0080 & $\mathrm{~A}$ & 13.4 & 105.9 & 4.9 & 10 \\
\hline Blackwater & 0.0436 & 0.0058 & $\mathrm{~A}, \mathrm{~B}$ & 15.9 & 89.9 & 4.9 & 10 \\
\hline West Looe & 0.0322 & 0.0049 & $\mathrm{~A}, \mathrm{~B}$ & 21.5 & 103.7 & 3.0 & 9 \\
\hline Tavy & 0.0250 & 0.0039 & $\mathrm{~B}, \mathrm{C}$ & 27.7 & 98.2 & 2.0 & 10 \\
\hline Restronguet Creek & 0.0172 & 0.0029 & $\mathrm{C}$ & 40.3 & 102.9 & 2.0 & 9 \\
\hline \multicolumn{8}{|l|}{ Zinc } \\
\hline Restronguet Creek & 0.0393 & 0.0034 & $\mathrm{~A}$ & 17.6 & 55.9 & 3.7 & 5 \\
\hline East Looe & 0.0389 & 0.0043 & $\mathrm{~A}$ & 17.8 & 54.8 & 3.7 & 7 \\
\hline Gannel & 0.0386 & 0.0038 & $\mathrm{~A}$ & 18.0 & 51.9 & 1.9 & 14 \\
\hline Blackwater & 0.0359 & 0.0024 & $\mathrm{~A}$ & 19.3 & 52.2 & 1.4 & 17 \\
\hline West Looe & 0.0321 & 0.0018 & $\mathrm{~A}$ & 21.6 & 54.0 & 1.4 & 17 \\
\hline Tavy & 0.0235 & 0.0018 & B & 29.5 & 54.0 & 2.4 & 10 \\
\hline
\end{tabular}




\section{Uptake and loss from ingested sediment}

$\mathrm{AE}$ is a measure of the amount of metal assimilated from a meal, i.e. the amount remaining in the body after the defaecation of the undigested portion of any meal. The AE of a radiolabelled metal, therefore, can be assessed from a plot of the change in radiolabelled count of the live animal after ingestion of a radiolabelled meal over the time period until defaecation is complete. If there is no subsequent excretion of assimilated metal, such a plot would level out at a constant percentage, which is a direct measure of the AE. If radiolabelled metal is excreted to any degree by the animal after assimilation, then counting over a longer period subsequent to assimilation and defaecation will provide an estimate of the excretion or efflux rate constant of this assimilated metal (see Fig. 3). A longer monitoring period also offers the opportunity to correct for any excretion of assimilated metal before defaecation is complete. A best-fit straight line regression plot of efflux over the latter part of the extended time series can be back-extrapolated to intercept the $y$-axis and provide a better estimate of the original AE. In practice, such a calculation is only necessary when the efflux rate of the assimilated metal is so high that excretion of assimilated metal before complete defaecation is significant. Values of AE calculated by back extrapolation usually do not differ from those estimated from visual inspection of a plot at the end of defaecation. Nevertheless back extrapolation has been used here to calculate AEs, for the relevant efflux data were collected as required for estimation of $K_{e}$ after assimilation from the diet. Typically, data after Day 2 were used in the back extrapolation, but in some individual cases, it was clear from the pattern of the data that defaecation had not yet been completed by Day 2, and a later count was chosen to start the data series used in back extrapolation, and indeed to calculate $\mathrm{K}_{\mathrm{e}}$.

Assimilation efficiencies for the $\mathrm{Cd}$ and $\mathrm{Zn}$ from radiolabelled sediment did not differ among the 6 populations (Table 5), with a grand mean of $61.9 \%( \pm 3.3$,

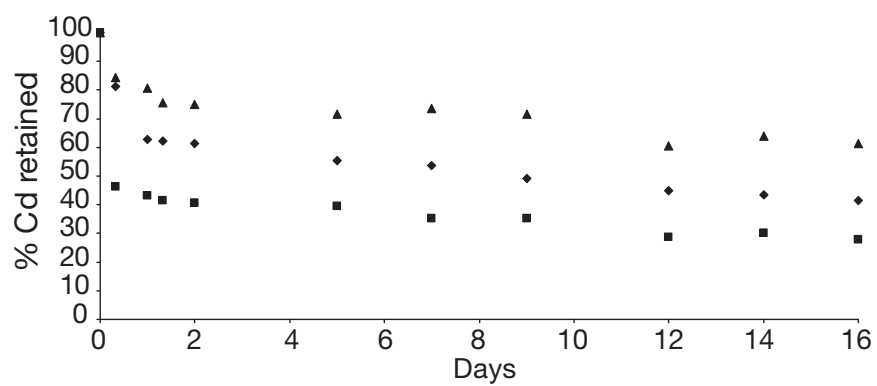

Fig. 3. Nereis diversicolor. Assimilation and subsequent efflux of radiolabelled Cd from individual worms (different symbols) from Restronguet Creek fed a single meal of radiolabelled sediment in a package of gelatine
$\mathrm{SE})$ for $\mathrm{Cd}$ and $46.7 \%( \pm 4.3, \mathrm{SE})$ for Zn. Like $\mathrm{K}_{\mathrm{u}} \mathrm{S}$, AEs for $\mathrm{Cd}$ and $\mathrm{Zn}$ do not appear to be very plastic. There was significant variation among the populations for the $\mathrm{Ag} \mathrm{AE}$, with the highest $\mathrm{AE}$ of $77.2 \%$ (Tavy) differing significantly from the lowest AE of $24.5 \%$ (Gannel). But the rank order of Ag AE did not follow the rank order of exposure history as measured by either sediment contamination or bioaccumulated Ag in the field (Table 1).

Efflux rate constants of metals taken up from ingested sediments did not differ among populations for either Cd or Ag (Table 6). There was a single significant difference between these constants in the case of $\mathrm{Zn}$, i.e. between populations from the Tavy and from East Looe (Table 6). The $\mathrm{K}_{\mathrm{e}}$ for $\mathrm{Zn}$ from the East Looe population was not significantly different from 0 (no significant efflux), although experimental variation caused an apparent positive slope.

\section{Efflux after uptake from solution or ingested sediment}

A comparison was made between efflux rate constants after uptake of radiolabelled metal from solution and ingested sediment (Table 7 ) in order to provide

Table 5. Nereis diversicolor. Assimilation efficiencies (AE: mean, $\mathrm{SE}$ ) of $\mathrm{Cd}, \mathrm{Ag}$ and $\mathrm{Zn}$ of the polychaete worm from each of 6 populations after ingestion of radiolabelled sediment packaged in gelatine. AE of worms from sites sharing a common letter for one metal in the a posteriori Tukey's test column do not differ significantly ( $p>0.05$ )

\begin{tabular}{|lcccc|}
\hline & AE (\%) & SE & $\mathrm{n}$ & Tukey's \\
\hline Cadmium & & & & \\
Gannel & 72.8 & 7.4 & 5 & $\mathrm{~A}$ \\
East Looe & 71.0 & 9.1 & 5 & $\mathrm{~A}$ \\
Restronguet Creek & 66.0 & 8.0 & 4 & $\mathrm{~A}$ \\
West Looe & 61.4 & 7.6 & 3 & $\mathrm{~A}$ \\
Blackwater & 50.7 & 5.1 & 7 & $\mathrm{~A}$ \\
Tavy & 50.0 & 9.1 & 3 & $\mathrm{~A}$ \\
Silver & & & & \\
Tavy & 77.2 & 7.6 & 7 & $\mathrm{~A}$ \\
West Looe & 52.8 & 17.1 & 4 & $\mathrm{~A}, \mathrm{~B}$ \\
Blackwater & 34.4 & 7.2 & 10 & $\mathrm{~A}, \mathrm{~B}$ \\
Restronguet Creek & 34.1 & & 1 & $\mathrm{~A}, \mathrm{~B}$ \\
East Looe & 29.3 & & 1 & $\mathrm{~A}, \mathrm{~B}$ \\
Gannel & 24.5 & 6.4 & 7 & $\mathrm{~B}$ \\
Zinc & & & & \\
Restronguet Creek & 65.3 & 4.4 & 4 & $\mathrm{~A}$ \\
West Looe & 58.8 & 9.0 & 3 & $\mathrm{~A}$ \\
East Looe & 46.1 & 7.2 & 5 & $\mathrm{~A}$ \\
Blackwater & 45.4 & 14.8 & 4 & $\mathrm{~A}$ \\
Tavy & 38.6 & 6.5 & 6 & $\mathrm{~A}$ \\
Gannel & 30.0 & 10.3 & 4 & $\mathrm{~A}$ \\
\hline
\end{tabular}


Table 6. Nereis diversicolor. Efflux rate constants $\left(\mathrm{K}_{\mathrm{e}}\right.$ : mean, $\left.\mathrm{SE}, \mathrm{d}^{-1}\right)$ and half times (the time for half of the metal in the pool to be excreted, d) of $\mathrm{Cd}, \mathrm{Ag}$ and $\mathrm{Zn}$ of polychaete worm from each of 6 populations ( 5 for $\mathrm{Ag}$ ) after ingestion of radiolabelled sediment packaged in gelatine. $\mathrm{K}_{\mathrm{e}}$ of worms from sites sharing a common letter for one metal in the a posteriori Tukey's test column do not differ significantly $(p>0.05)$

\begin{tabular}{|lccccc|}
\hline & $\mathrm{K}_{\mathrm{e}}$ & $\mathrm{SE}$ & Half time & $\mathrm{n}$ & Tukey's \\
\hline Cadmium & & & & & \\
East Looe & 0.0261 & 0.0091 & 26.6 & 5 & $\mathrm{~A}$ \\
Restronguet Creek & 0.0246 & 0.0043 & 28.2 & 3 & $\mathrm{~A}$ \\
Blackwater & 0.0232 & 0.0029 & 29.9 & 7 & $\mathrm{~A}$ \\
Gannel & 0.0177 & 0.0042 & 39.2 & 4 & $\mathrm{~A}$ \\
Tavy & 0.0163 & 0.0063 & 42.5 & 3 & $\mathrm{~A}$ \\
West Looe & 0.0115 & 0.0022 & 60.3 & 3 & $\mathrm{~A}$ \\
Silver & & & & & \\
Blackwater & 0.0835 & 0.0165 & 8.3 & 9 & $\mathrm{~A}$ \\
Gannel & 0.0628 & 0.0172 & 11.0 & 7 & $\mathrm{~A}$ \\
Restronguet Creek & 0.0619 & & 11.2 & 1 & $\mathrm{~A}$ \\
West Looe & 0.0532 & 0.0109 & 13.0 & 4 & $\mathrm{~A}$ \\
Tavy & 0.0440 & 0.0132 & 15.8 & 6 & $\mathrm{~A}$ \\
Zinc & & & & & \\
Tavy & 0.0712 & 0.0229 & 9.7 & 6 & $\mathrm{~A}$ \\
Restronguet Creek & 0.0441 & 0.0193 & 15.7 & 4 & $\mathrm{~A}, \mathrm{~B}$ \\
West Looe & 0.0292 & 0.0103 & 23.7 & 5 & $\mathrm{~A}, \mathrm{~B}$ \\
Gannel & 0.0170 & 0.0147 & 40.8 & 4 & $\mathrm{~A}, \mathrm{~B}$ \\
Blackwater & 0.0059 & 0.0098 & 117.5 & 4 & $\mathrm{~A}, \mathrm{~B}$ \\
East Looe & +0.0037 & 0.0104 & 187.3 & 5 & $\mathrm{~B}$ \\
\hline & & & & & \\
\hline
\end{tabular}

\section{Relationship between uptake and efflux rates}

Data were available for individual worms, so we were able to investigate whether there was any relationship between rates of uptake from solution and subsequent efflux rate constants for metals accumulated by this route. There were no significant regressions ( $\mathrm{p}>0.05$ ) between $\mathrm{K}_{\mathrm{u}}$ and $\mathrm{K}_{\mathrm{e}}$ for either $\mathrm{Cd}$ or $\mathrm{Ag}$ from the slow pool for any population. Indeed, there was also no significant regression in the case of $\mathrm{Zn}$ for 5 of the 6 populations, although there was a was a significant regression $\left(F_{\mathrm{s}}=19.74 ; \mathrm{df}=1,12 ; \mathrm{p}<0.001\right)$ for $\mathrm{Zn}$ uptake and efflux rates in worms from the Gannel.

\section{Seasonal comparison}

Such a large programme of experiments inevitably takes time, for example from April to October in 2007, with the potential for seasonal effects on the parameters measured. We took the opportunity to repeat one full set of experiments in order to check for seasonal changes. Thus, Table 8 reports data on $\mathrm{Zn}$ uptake from solution for the 6 populations collected in September insight on whether metal taken up from the 2 different routes might be accumulating in the same or different pools in the organism (e.g. Hook \& Fisher 2001).

There was no significant difference between the 2 efflux rate constants for any population in the case of accumulated cadmium. The silver database was more limited (Table 7), but where comparisons were possible, $\mathrm{K}_{\mathrm{e}}$ was higher in the case of Ag accumulated after uptake from ingested sediment. The difference was significant for the population from the Blackwater but not significant for Tavy and West Looe populations (Table 7). In the case of zinc, the situation was the reverse of that for silver, with lower efflux rate constants for accumulated metal taken up from ingested sediment. The difference was significant for 3 populations (Blackwater, East Looe, Tavy), but not in the case of the zinc-tolerant Restronguet Creek population (Table 7).
Table 7. Nereis diversicolor. Comparison of efflux rate constants $\left(\mathrm{K}_{\mathrm{e}}\right.$ : mean, $\mathrm{SE}$, $\mathrm{d}^{-1}$ ) of $\mathrm{Cd}, \mathrm{Ag}$ and $\mathrm{Zn}$ in polychaete worms from each of 6 populations after taking up radiolabelled metal either from solution or from ingested sediment. 2007 data. ns: no significant difference, $\mathrm{p}>0.05$

\begin{tabular}{|lccccccc|}
\hline & \multicolumn{3}{c}{$\mathrm{K}_{\mathrm{e}}$ solution } & \multicolumn{5}{c}{$\mathrm{K}_{\mathrm{e}}$ ingested sediment } & ANOVA \\
& $\mathrm{K}_{\mathrm{e}}$ & $\mathrm{SE}$ & $\mathrm{n}$ & $\mathrm{K}_{\mathrm{e}}$ & $\mathrm{SE}$ & $\mathrm{n}$ & \\
\hline Cadmium & & & & & & & \\
Blackwater & 0.0184 & 0.0018 & 14 & 0.0232 & 0.0029 & 7 & $\mathrm{~ns}$ \\
East Looe & 0.0217 & 0.0029 & 14 & 0.0261 & 0.0091 & 5 & $\mathrm{~ns}$ \\
Gannel & 0.0336 & 0.0046 & 14 & 0.0177 & 0.0042 & 4 & $\mathrm{~ns}$ \\
Restronguet Creek & 0.0312 & 0.0046 & 14 & 0.0246 & 0.0043 & 3 & $\mathrm{~ns}$ \\
Tavy & 0.0311 & 0.0050 & 14 & 0.0163 & 0.0063 & 3 & $\mathrm{~ns}$ \\
West Looe & 0.0243 & 0.0027 & 13 & 0.0115 & 0.0022 & 3 & $\mathrm{~ns}$ \\
Silver & & & & & & & \\
Blackwater & 0.0436 & 0.0058 & 10 & 0.0835 & 0.0165 & 9 & $\mathrm{p}<0.05$ \\
East Looe & 0.0518 & 0.0080 & 10 & - & - & - & \\
Gannel & - & - & - & 0.0628 & 0.0172 & 7 & \\
Restronguet Creek & 0.0172 & 0.0029 & 9 & 0.0619 & & 1 & \\
Tavy & 0.0250 & 0.0039 & 10 & 0.0440 & 0.0132 & 6 & $\mathrm{~ns}$ \\
West Looe & 0.0322 & 0.0049 & 9 & 0.0532 & 0.0109 & 4 & $\mathrm{~ns}$ \\
Zinc & & & & & & & \\
Blackwater & 0.0359 & 0.0024 & 17 & 0.0059 & 0.0098 & 4 & $\mathrm{p}<0.001$ \\
East Looe & 0.0389 & 0.0043 & 7 & +0.0037 & 0.0104 & 5 & $\mathrm{p}<0.001$ \\
Gannel & 0.0386 & 0.0038 & 14 & 0.0170 & 0.0147 & 4 & $\mathrm{~ns}$ \\
Restronguet Creek & 0.0393 & 0.0034 & 5 & 0.0441 & 0.0193 & 4 & $\mathrm{~ns}$ \\
Tavy & 0.0235 & 0.0018 & 10 & 0.0712 & 0.0229 & 6 & $\mathrm{p}<0.05$ \\
West Looe & 0.0321 & 0.0018 & 17 & 0.0292 & 0.0103 & 5 & $\mathrm{~ns}$ \\
& & & & & & & \\
\hline
\end{tabular}


Table 8. Nereis diversicolor. Autumn 2006 and summer 2007 uptake rate constants $\left(\mathrm{K}_{\mathrm{u}}\right.$ : mean, SE, $\left.1 \mathrm{~g}^{-1} \mathrm{~d}^{-1}\right)$ of $\mathrm{Zn}$ in polychaete worms from each of 6 populations taking up radiolabelled metal from solution. ANOVA compares 2006 and 2007 regression data generating $K_{u}$ for each population (ns: no significant difference, $p>0.05$ ). $K_{u}$ (combined 2006 and 2007 data) of worms from sites sharing a common letter in the a posteriori Tukey's test column do not differ significantly $(p>0.05)$

\begin{tabular}{|c|c|c|c|c|c|c|c|c|c|c|c|}
\hline & \multirow{2}{*}{\multicolumn{3}{|c|}{2006 data -}} & \multirow{2}{*}{\multicolumn{3}{|c|}{-2007 data -}} & \multirow[t]{3}{*}{ ANOVA } & \multirow{2}{*}{\multicolumn{3}{|c|}{$\begin{array}{c}\text { Combined } \\
2006 / 2007 \text { data }\end{array}$}} & \multirow[t]{3}{*}{ Tukey's } \\
\hline & & & & & & & & & & & \\
\hline & $\mathrm{K}_{\mathrm{u}}$ & $\mathrm{SE}$ & $\mathrm{n}$ & $\mathrm{K}_{\mathrm{u}}$ & $\mathrm{SE}$ & $\mathrm{n}$ & & $\mathrm{K}_{\mathrm{u}}$ & $\mathrm{SE}$ & $\mathrm{n}$ & \\
\hline Blackwater & 0.0398 & 0.0045 & 20 & 0.1021 & 0.0346 & 17 & ns & 0.0894 & 0.0187 & 37 & A \\
\hline East Looe & 0.0254 & 0.0035 & 20 & 0.0173 & 0.0366 & 7 & ns & 0.0479 & 0.0181 & 27 & A \\
\hline Gannel & 0.0369 & 0.0135 & 20 & 0.0859 & 0.0297 & 14 & ns & 0.0799 & 0.0173 & 34 & $\mathrm{~A}$ \\
\hline Restronguet Creek & 0.0621 & 0.0162 & 20 & 0.0660 & 0.0734 & 7 & ns & 0.0777 & 0.0211 & 27 & $\mathrm{~A}$ \\
\hline Tavy & 0.0470 & 0.0070 & 19 & 0.0752 & 0.0208 & 10 & ns & 0.0695 & 0.0121 & 29 & $\mathrm{~A}$ \\
\hline West Looe & 0.0369 & 0.0083 & 19 & 0.0336 & 0.0100 & 16 & ns & 0.0570 & 0.0105 & 35 & A \\
\hline
\end{tabular}

2006 and April 2007. In no case was there a significant difference in the uptake rate constants. All other comparisons made concern only data collected between April and October 2007.

\section{DISCUSSION}

We measured parameters of the bioaccumulation kinetics of the toxic metals Ag, $\mathrm{Cd}$ and $\mathrm{Zn}$ in populations of Nereis diversicolor from the differentially metal-contaminated sediments of 5 metal-rich estuaries and a relatively non-contaminated control estuary, i.e. uptake rate constants from solution and assimilation efficiencies from sediment, and subsequent efflux rate constants after uptake from either water or ingested sediment. We hypothesized that populations from estuaries with large differences in exposure history would be the most likely to show interpopulation variation in these parameters were selective pressure being exerted on worms exposed to atypically high local bioavailabilities of a toxic metal. Differences in physiological traits among these field populations might also elucidate the mechanisms involved in the development of tolerance in this species. One population (from Restronguet Creek, Cornwall) is known to be tolerant to raised availabilities of zinc in response to the very high local sediment $\mathrm{Zn}$ bioavailabilities (Bryan \& Hummerstone 1971, 1973, Bryan \& Gibbs 1983, Grant et al. 1989, Mouneyrac et al. 2003), and thus represented a good candidate population to seek such evidence for selection.

The first parameter measured was the uptake rate constant $\mathrm{K}_{\mathrm{u}}$ (Table 3), defining the rate of uptake from solution. For $\mathrm{Cd}$ and $\mathrm{Zn}$ uptake rate constants, there was only a single significant difference between 2 populations. This difference was for the $\mathrm{Cd} \mathrm{K}_{\mathrm{u}}$ between Tavy (high) and the Zn-tolerant population at Restronguet Creek (low) in the expected direction, but the Restronguet Creek $K_{u}$ was not different from that of any other population. There may be an association between the relatively high sedimentary bioavailability of $\mathrm{Cd}$ to Nereis diversicolor (Table 1) and a relatively high $\mathrm{Cd} \mathrm{K}_{\mathrm{u}}$ (Table 3 ) at Tavy, but the evidence is not convincing. There was greater interpopulation variation in the $K_{u}$ of Ag than for the other 2 metals, with the Tavy and Restronguet Creek populations showing high Ag uptake and the Gannel population the lowest (Table 3). Restronguet Creek did show relatively high sedimentary Ag bioavailability to $N$. diversicolor (Table 1), but this was not the case for the Tavy (Table 1). The Gannel appears to have the lowest Ag bioavailability to the worms (Table 1). In conclusion, therefore, there is a suggestion that there may be a relationship for the worms between the $\mathrm{K}_{\mathrm{u}}$ of either $\mathrm{Cd}$ or Ag and local bioavailability, but the evidence is hardly strong. On the other hand, there has been no effect on $\mathrm{Zn}$ uptake rate by the worms by increased local exposure to $\mathrm{Zn}$, even though the high local bioavailability in Restronguet Creek has been sufficient to select for a Zn-tolerant population.

Rainbow et al. (1999) explored population differences in $\mathrm{Zn}, \mathrm{Cd}$ and $\mathrm{Ag}$ uptake rates (from solution) of amphipods Orchestia gammarellus and crabs Carcinus maenas collected from different metal-contaminated sites, including Restronguet Creek, but these did not show any consistent significant interpopulation differences, leading to the conclusion that the differential exposure of the amphipods and crabs had not been sufficient to select for a reduction in dissolved metal uptake rates (Rainbow et al. 1999). Both the amphipods and crabs live further down estuaries than Nereis diversicolor, leading to the possibility that the worms would be exposed to higher local metal bioavailabilities than the 2 crustaceans (the metal sources lying upstream), with consequently higher metal exposure. Even so, there has been no selection for reduced uptake rates of metals from solution in the polychaete worm. Similarly, in the case of the barnacle Balanus amphitrite collected from sites with different degrees 
of metal contamination in Hong Kong waters, there was no significant correlation between $\mathrm{Cd}$ or $\mathrm{Zn}$ dissolved uptake rate and history of previous metal exposure (Rainbow et al. 2003). Furthermore, feeding on $\mathrm{Cd}$ or Ag-enriched diatoms by this barnacle did not change rates of uptake of $\mathrm{Cd}, \mathrm{Zn}$ or Ag from solution (Rainbow et al. 2004). In the same vein, Shi \& Wang (2004) found no significant difference in the dissolved uptake rate constants for $\mathrm{Cd}$ between 2 populations of clams Ruditapes philippinarum collected from a metalcontaminated bay and a relatively clean site.

Thus, even when there is variation in uptake rates of dissolved metals among populations exposed to different metal bioavailabilities in the field or laboratory, there appears to be no consistent relation between high metal bioavailability and the uptake rate constant of the exposed populations. Correspondingly, the tolerance of the Restronguet Creek population of Nereis diversicolor to zinc is not associated with a reduced uptake rate of $\mathrm{Zn}$ from solution.

A second parameter of the bioaccumulation kinetics that might vary between populations is the efflux rate constant after uptake of metals from solution. In the case of $\mathrm{Zn}$, there was no significant difference in this $K_{e}$ across the populations except for a significantly lower efflux rate constant for the Tavy population (Table 4). Increased excretion of zinc taken up from solution is not therefore part of the $\mathrm{Zn}$ tolerance mechanism of the Restronguet Creek Nereis diversicolor population. There was no significant interpopulation variation in this $\mathrm{K}_{\mathrm{e}}$ for Cd (Table 4). As for $\mathrm{Ag} \mathrm{K}_{\mathrm{u}}, \mathrm{Ag} \mathrm{K} \mathrm{K}_{\mathrm{e}}$ did show significant variation among populations (Table 4), but there is no clear pattern discernible between this $\mathrm{K}_{\mathrm{e}}$ and apparent local differences in $\mathrm{Ag}$ bioavailability to the worms (Table 1).

There are few available comparative interpopulational data for $\mathrm{K}_{\mathrm{e}}$ after uptake from solution. Shi \& Wang (2004) found no significant differences between the Cd efflux rate constants of 2 populations of Ruditapes philippinarum from metal-contaminated and relatively clean sites.

Given the importance of the sediment as a metal source to Nereis diversicolor, it could be argued that there might be greater selection acting on the assimilation efficiencies of metals by the worm than in the case of dissolved uptake. In fact, there was no difference among all 6 populations in the $\mathrm{AE}$ of either $\mathrm{Cd}$ or $\mathrm{Zn}$ (Table 5). In contrast, Ag AE varied widely with a significant difference between a high mean of $77.2 \%$ for the Tavy population and a low mean of $24.5 \%$ for the Gannel population, although neither of these 2 populations differed from any of the other populations (Table 5). This variability, however, was not tied in a simple way to either Ag concentrations in sediments or bioaccumulated Ag concentrations as measures of exposure (Table 1).
In cases of other aquatic invertebrates, there were no significant differences in the AEs of $\mathrm{Cd}, \mathrm{Zn}$ or $\mathrm{Ag}$ among populations of the barnacle Balanus amphitrite collected from sites with different degrees of metal contamination in Hong Kong waters (Rainbow et al. 2003). Similarly, nor was there a clear consistent effect of dietary pre-exposure of the barnacles to $\mathrm{Cd}$ or $\mathrm{Ag}$ on their AE of Cd, Zn or Ag (Rainbow et al. 2004). On the other hand, Shi \& Wang (2004) did find significantly higher $\mathrm{Cd}$ and $\mathrm{Zn}$ assimilation efficiencies in a population of Ruditapes philippinarum collected from a metal-contaminated bay compared to a population collected from a relatively clean site.

The final parameter compared was the efflux rate constant Ke after uptake of metal from ingested sediment. There was no significant interpopulation difference for this parameter across the populations for either Cd or Ag (Table 6). The case of $\mathrm{Zn}$ is more complex. There was no rank order correspondence between the rate constants of loss after $\mathrm{Zn}$ ingestion (Table 6) and the indicators of $\mathrm{Zn}$ exposure (Table 1). But the 2 populations of Nereis diversicolor (Tavy and Restronguet Creek) in which regulation of total body $Z n$ had broken down (Table 1) showed the highest $K_{e}$ (Table 6). The possibility of enhanced $\mathrm{Zn}$ excretion contributing to the survival of the worms in Restronguet Creek probably should not be discounted.

Comparatively, there were no significant differences in the $\mathrm{K}_{\mathrm{e}}$ of $\mathrm{Cd}$, Zn or Ag after dietary uptake among populations of the barnacle Balanus amphitrite from the different metal-contaminated sites in Hong Kong waters (Rainbow et al. 2003), nor in the $\mathrm{K}_{\mathrm{e}}$ of $\mathrm{Cd}$ or $\mathrm{Zn}$ after dietary pre-exposure of the barnacles to $\mathrm{Cd}$ or $\mathrm{Ag}$ (Rainbow et al. 2004). Combinations of $\mathrm{Ag} / \mathrm{Cd}$ dietary pre-exposure did, however, increase the $\mathrm{Ag} \mathrm{K}_{\mathrm{e}}$ of $B$. amphitrite (Rainbow et al. 2004).

What can be concluded about interpopulation differences in the 4 measured parameters of bioaccumulation kinetics of the 3 metals by the worm Nereis diversicolor, given that the worms live in sediments of varying bioavailabilities of the metal, especially so in the case of zinc? For $\mathrm{Zn}$, there was no significant interpopulation variation in the rates of uptake, either from solution or, arguably more importantly, from ingested sediment. Clearly the $\mathrm{Zn}$ tolerance of the Restronguet Creek population has not been brought about by selection for reduced uptake of $\mathrm{Zn}$. There was no significant interpopulation variation in the efflux rate constants of accumulated $\mathrm{Zn}$ after uptake from solution, and only one significant interpopulation difference in $K_{e}$ after uptake from ingested sediment. The $\mathrm{Zn}$ efflux rate constants of the Restronguet Creek population were not atypical, although arguably high in the case of efflux after ingestion. Thus the $\mathrm{Zn}$ tolerance mechanism of this population cannot be put down to selection 
for increased efflux either. $N$. diversicolor typically regulates the accumulated body concentration of $\mathrm{Zn}$ to an approximately constant level (Bryan \& Hummerstone 1973, Bryan et al. 1980, Amiard et al. 1987), regulation being brought about by a matching of efflux rate to total uptake rate until such a point that uptake rate exceeds the efflux rate achievable and net accumulation ensues (Rainbow 2002). This accumulated metal must be detoxified or toxicity occurs (Rainbow 2002). Any Zn regulation has clearly broken down in the case of the Restronguet Creek population (and perhaps also in the Tavy population) (Table 1), but the rate of detoxification must have matched the excess rate of accumulation caused by the difference between uptake and efflux rates. Thus the basis of $\mathrm{Zn}$ tolerance in the Restronguet Creek population of $N$. diversicolor appears to be an increased capacity for (rate of) storage detoxification after $\mathrm{Zn}$ regulation has broken down. The major detoxified stores of $\mathrm{Zn}$ in this population are spherocrystals in the gut wall (Mouneyrac et al. 2003). These spherocrystals can potentially be excreted from the gut and therefore form the basis of the somewhat raised $K_{e}$ shown in Table 6 , even though this efflux does not match total Zn uptake, and Zn bioaccumulation to a high concentration ensues (Table 1).

The basis of the same population's tolerance to copper also appears to be increased capacity for detoxification and not reduced uptake (Bryan \& Hummerstone 1971). The detoxified $\mathrm{Cu}$ stores are $\mathrm{Cu}$ and sulphur-rich lysosomal residual bodies in the epidermis, and $\mathrm{Cu}$ - and S-rich extracellular granules in the epicuticle (Mouneyrac et al. 2003), possibly derived therefrom.

The biodynamic parameters of $\mathrm{Cd}$ bioaccumulation showed no interpopulation variation except for a single significant difference between uptake rate constants for dissolved $\mathrm{Cd}$ uptake between the Tavy and Restronguet Creek populations. Given that this latter population showed no significant difference in $\mathrm{K}_{\mathrm{u}}$ from any other population, reduced $\mathrm{Cd}$ uptake from solution does not appear to be a feature of the Zn-tolerant population, which would be a possibility given the sharing of uptake routes by $\mathrm{Zn}$ and $\mathrm{Cd}$ (Luoma \& Rainbow 2008). The significantly raised $\mathrm{Cd} \mathrm{K}_{\mathrm{u}}$ in the Tavy population may play a part in the slightly raised accumulated $\mathrm{Cd}$ concentration in Tavy worms in the absence of very high total $\mathrm{Cd}$ sediment concentrations (Table 1).

Silver showed the most interpopulation variation in biodynamic parameters of bioaccumulation. The Tavy population had the highest $\mathrm{Ag} \mathrm{K}_{\mathrm{u}}$ and $\mathrm{AE}$, while the $\mathrm{K}_{\mathrm{e}}$ after uptake from water was somewhat low, and the $K_{e}$ after sediment ingestion also low but not significantly different from that of any other population. In spite of high uptake rates and possibly low efflux, this Tavy population did not show atypically raised Ag accumulation (Table 1). The variability in Ag bioaccumulation parameters showed no consistent pattern with Ag exposure, and may be related to differences in local $\mathrm{Cu}$ bioavailabilities, as $\mathrm{Cu}$ and Ag do share uptake pathways (Luoma \& Rainbow 2008). The Cu-tolerant Restronguet Creek population had a high accumulated Ag concentration reflecting the high total Ag concentration of the sediment (Table 1); its uptake and efflux parameters for Ag, however, were not atypical, indicating that any mechanism of tolerance to $\mathrm{Cu}$ has not affected the biodynamics of Ag uptake and efflux.

The data do allow addressing the question of whether metals taken up from the 2 routes share the same detoxification and, potentially, excretion pathway as reflected in efflux rate constants that are the same. This was the case for $\mathrm{Cd}$. The presence of different efflux characteristics after uptake from solution and diet suggests that different excretion pathways might be involved. For example, there appeared to be greater efflux of Ag after uptake from ingested sediment as opposed to solution, suggesting that different physiological handling processes are involved. For Zn, however, efflux was lower after $\mathrm{Zn}$ uptake in the gut. Given that a $\mathrm{Zn}$ detoxification route in these worms can involve Zn-rich spherocrystals in the gut wall (Mouneyrac et al. 2003), it would appear that this route is particularly pertinent for $\mathrm{Zn}$ assimilated in the gut and causes longer retention of the accumulated $\mathrm{Zn}$ than any route used to process $\mathrm{Zn}$ taken up from solution.

\section{LITERATURE CITED}

Amiard JC, Amiard-Triquet C, Berthet B, Métayer C (1987) Comparative study of the patterns of bioaccumulation of essential $(\mathrm{Cu}, \mathrm{Zn})$ and non-essential $(\mathrm{Cd}, \mathrm{Pb})$ trace metals in various estuarine and coastal organisms. J Exp Mar Biol Ecol 106:73-89

> Berthet B, Mouneyrac C, Amiard JC, Amiard-Triquet C and others (2003) Responses to metals of the polychaete annelid Hediste diversicolor, a key species in estuarine and coastal sediments. Arch Environ Contam Toxicol 45: $468-478$

Boisson F, Hartl MGJ, Fowler SW, Amiard-Triquet C (1998) Influence of chronic exposure to silver and mercury in the field on the bioaccumulation potential of the bivalve Macoma balthica. Mar Environ Res 45:325-340

Bryan GW, Gibbs PE (1983) Heavy metals in the Fal Estuary, Cornwall: a study of long-term contamination by mining waste and its effects on estuarine organisms. Occ Publ Mar Biol Assoc UK 2:1-112

Bryan GW, Hummerstone LG (1971) Adaptation of the polychaete Nereis diversicolor to estuarine sediments containing high concentrations of heavy metals. I. General observations and adaptation to copper. J Mar Biol Assoc UK 51:845-863

Bryan GW, Hummerstone LG (1973) Adaptation of the polychaete Nereis diversicolor to estuarine sediments contain- 
ing high concentrations of zinc and cadmium. J Mar Biol Assoc UK 53:839-857

Bryan GW, Langston WJ, Hummerstone LG (1980) The use of biological indicators of heavy metal contamination in estuaries. Occ Publ Mar Biol Assoc UK 1:1-73

Bryan GW, Langston WJ, Hummerstone LG, Burt GR (1985) A guide to the assessment of heavy-metal contamination in estuaries. Occ Publ Mar Biol Assoc UK 4:1-92

Cain DJ, Buchwalter DB, Luoma SN (2006) Influence of metal exposure history on the bioaccumulation and subcellular distribution of aqueous cadmium in the insect Hydropsyche californica. Environ Toxicol Chem 25:1042-1049

Cheung MS, Wang WX (2005) Influences of subcellular compartmentalization in different prey on the transfer of metals to a predatory gastropod. Mar Ecol Prog Ser 286: 155-166

Croteau MN, Luoma SN (2005) Delineating copper accumulation pathways for the freshwater bivalve Corbicula using stable copper isotopes. Environ Toxicol Chem 24: 2871-2878

Grant A, Hateley JG, Jones NV (1989) Mapping the ecological impact of heavy metals in the estuarine polychaete Nereis diversicolor using inherited metal tolerance. Mar Pollut Bull 20:235-238

Harley MB (1950) Occurrence of a filter feeding mechanism in the polychaete Nereis diversicolor. Nature 165:734-735

> Hook SE, Fisher NS (2001) Sublethal effects of silver in zooplankton: importance of exposure pathways and implications for toxicity testing. Environ Toxicol Chem 20:568-574

Klerks PL, Weis JS (1987) Genetic adaptation to heavy metals in aquatic organisms: a review. Environ Pollut 45:173-205

> Levinton JS, Suatoni E, Wallace W, Junkins R, Kelaher B, Allen BJ (2003) Rapid loss of genetically based resistance to metals after the cleanup of a Superfund site. Proc Natl Acad Sci USA 100:9889-9891

Luoma SN (1977) Detection of trace contaminant effects in aquatic ecosystems. J Fish Res Board Can 34:436-439

Luoma SN, Rainbow PS (2005) Why is metal bioaccumulation so variable? Biodynamics as a unifying concept. Environ Sci Technol 39:1921-1931

Luoma SN, Rainbow PS (2008) Metal contamination in aquatic environments: science and lateral management. Cambridge University Press, Cambridge

Luoma SN, Cain DJ, Ho D, Hutchinson A (1983) Variable tolerance to copper in two species from San Francisco Bay. Mar Environ Res 10:209-222

Millward RN, Grant A (1995) Assessing the impact of copper on nematode communities from a chronically metalenriched estuary using pollution-induced community

Editorial responsibility: Mike Elliott,

Hull, UK tolerance. Mar Pollut Bull 30:701-706

> Mouneyrac C, Mastain O, Amiard JC, Amiard-Triquet C and others (2003) Trace-metal detoxification and tolerance of the estuarine worm Hediste diversicolor chronically exposed in their environment. Mar Biol 143:731-744

Postma JF, van Nugteren P, Buckert-de Jong MB (1996) Increased cadmium excretion in metal-adapted populations of the midge Chironomus riparius (Diptera). Environ Toxicol Chem 15:332-339

Rainbow PS (2002) Trace metal concentrations in aquatic invertebrates: why and so what? Environ Pollut 120: 497-507

Rainbow PS, Amiard-Triquet C, Amiard JC, Smith BD, Best SL, Nassiri Y, Langston WJ (1999) Trace metal uptake rates in crustaceans (amphipods and crabs) from coastal sites in NW Europe differentially enriched with trace metals. Mar Ecol Prog Ser 183:189-203

Rainbow PS, Blackmore G, Wang WX (2003) Effects of previous field-exposure history on the uptake of trace metals from water and food by the barnacle Balanus amphitrite. Mar Ecol Prog Ser 259:201-213

> Rainbow PS, Ng TYT, Shi D, Wang WX (2004) Acute dietary pre-exposure and trace metal bioavailability to the barnacle Balanus amphitrite. J Exp Mar Biol Ecol 311:315-337

Rainbow PS, Amiard JC, Amiard-Triquet C, Cheung MS, Zhang L, Zhong H, Wang WX (2007) Trophic transfer of trace metals: subcellular compartmentalization in bivalve prey, assimilation by a gastropod predator and in vitro digestion simulations. Mar Ecol Prog Ser 348:125-138

> Shi D, Wang WX (2004) Understanding the differences in Cd and $\mathrm{Zn}$ bioaccumulation and subcellular storage among different populations of marine clams. Environ Sci Technol 38:449-456

> Wallace WG, Lopez GR, Levinton JS (1998) Cadmium resistance in an oligochaete and its effect on cadmium trophic transfer to an omnivorous shrimp. Mar Ecol Prog Ser 172: 225-237

> Wang WX, Fisher NS (1999) Assimilation efficiencies of chemical contaminants in aquatic invertebrates: a synthesis. Environ Toxicol Chem 18:2034-2045

Wang WX, Rainbow PS (2005) Influence of pre-exposure on trace metal uptake in marine invertebrates. Ecotoxicol Environ Saf 61:145-159

Wang WX, Rainbow PS (2006) Subcellular partitioning and the prediction of cadmium toxicity to aquatic organisms. Environ Chem 3:395-399

Wang WX, Fisher NS, Luoma SN (1996) Kinetic determinations of trace element bioaccumulation in the mussel Mytilus edulis. Mar Ecol Prog Ser 140:91-113

Submitted: August 29, 2008; Accepted: November 9, 2008 Proofs received from author(s): January 30, 2009 